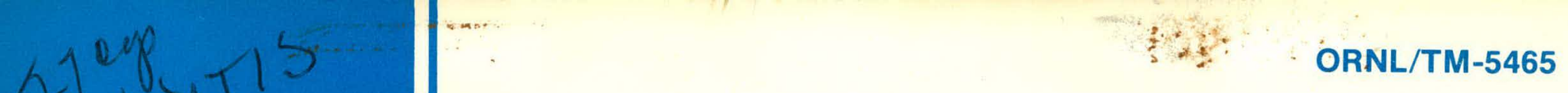

\title{
Isotope Separations Section Progress Report for Quarter Ending March 31, 1976
}

\author{
E. Newman
}

\section{OAK RIDGE NATIONAL LABORATORY}

OPERATED BY UNION CARBIDE CORPORATION FOR THE ENERGY RESEARCH AND DEVELOPMENT ADMINISTRATION 


\section{DISCLAIMER}

This report was prepared as an account of work sponsored by an agency of the United States Government. Neither the United States Government nor any agency Thereof, nor any of their employees, makes any warranty, express or implied, or assumes any legal liability or responsibility for the accuracy, completeness, or usefulness of any information, apparatus, product, or process disclosed, or represents that its use would not infringe privately owned rights. Reference herein to any specific commercial product, process, or service by trade name, trademark, manufacturer, or otherwise does not necessarily constitute or imply its endorsement, recommendation, or favoring by the United States Government or any agency thereof. The views and opinions of authors expressed herein do not necessarily state or reflect those of the United States Government or any agency thereof. 


\section{DISCLAIMER}

Portions of this document may be illegible in electronic image products. Images are produced from the best available original document. 
Printed in the United States of America. Available from

National Technical Information Service

U.S. Department of Commerce

5285 Port Royal Hoad, Springlield, Virginia 22161

Price: Printed Copy $\$ 3.50$; Microfiche $\$ 2.25$

This report was prepared as an account of work sponsored by the United States Government. Neither the United States nor the Energy Research and Development Administration/United States Nuclear Regulatory Commission, nor any of their employees, nor any of their contractors, subcontractors, or their employees, makes any warranty, express or implied, or assumes any legal liability or responsibility for the accuracy, completeness or usefulness of any information, apparatus, product or process disclosed, or represents that its use would not infringe privately owned rights. 
Contract No. W-7405-eng-26

CHEMICAL TECHNOLOGY DIVISION

ISOTOPE SEPARATIONS SECTION PROGRESS REPORT

FOR QUARTER EMDINC MARCH 31,1976

\section{E. Newman}

Compiled from contributions by:

W. A. Be11, Jr.

H. H. Caudill

W. C. Davis

J. G. Tracy

J. W. York

JUNE 1976

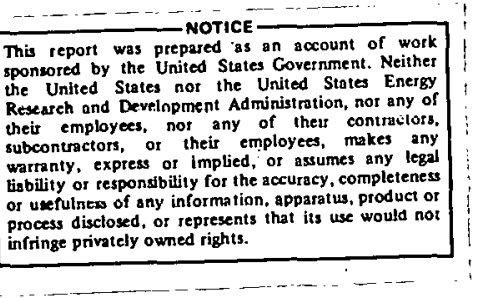

NOTICE This document contains information of a preliminary nature ano was propared jurimorlly for internal ues at the Oak Ridge National Leboratory. It is subject to revision or correction and therefore does not represent a final report.

OAK RIDGE NATIONAL LABORATORY

Oak Ridge, Tennessee 37830

operated by

UNION CARBIDE CORPORATION

for the

ENERGY RESEARCH AND DEVELOPMENT ADMINISTRATION 
THIS PAGE

\section{WAS INTENTIONALLY \\ LEFT BLANK}


CONTENTS

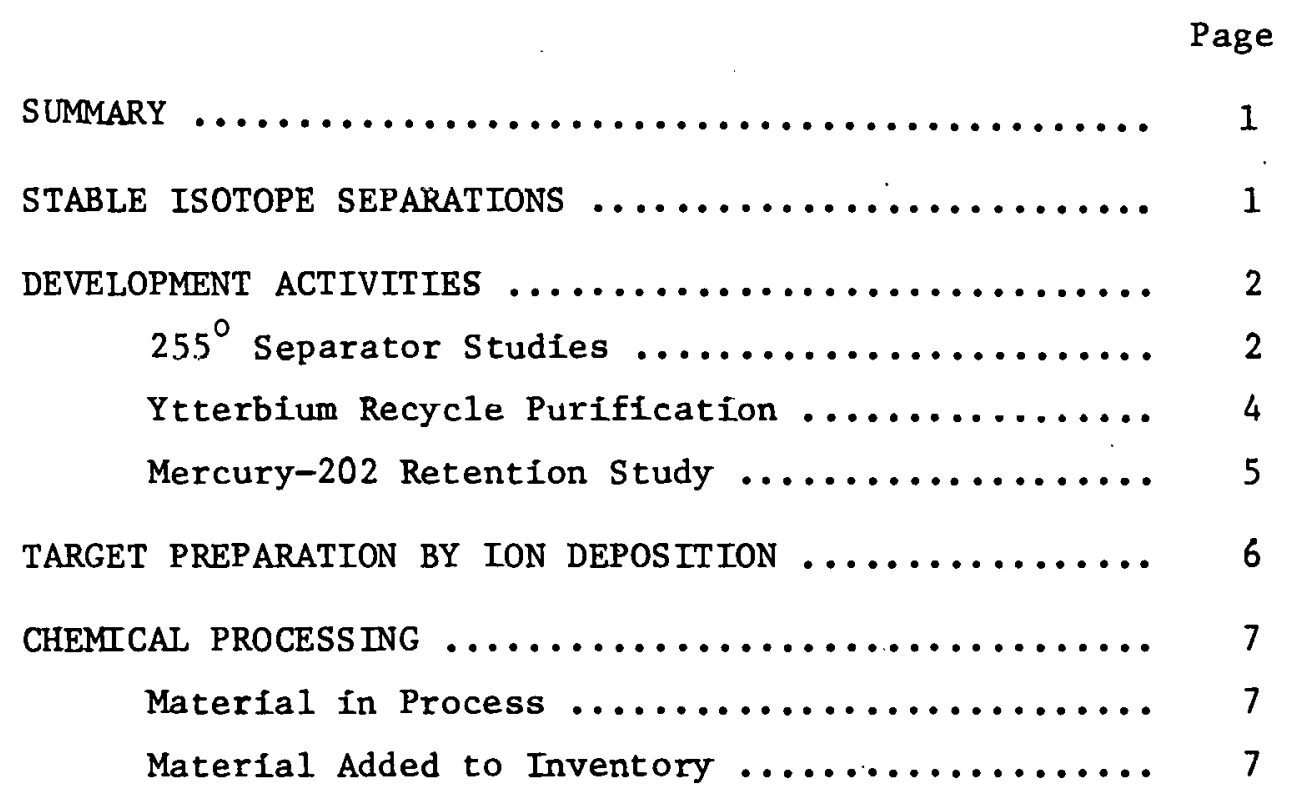


ISOTOPE SEPARATIONS SECTION PROGRESS REPORT

FOR QUARTER ENDING MARCH 31,1976

\section{E. Newman}

\section{SUMMARY}

The activities of the Isotope Separations Section of the Chemical Technology Division are described for the quarter ending March 31, 1976. Included is the status of the current electromagnetic separation of the isotopes of chlorine, tin, and ytterbium. The research and development activities on the $255^{\circ}$ separators to improve the isotopic purity of germanium isotopes are also discussed. An improved chemical recoveryrecycle system for ytterbium charge material and a study of the factors involved in recovering ${ }^{202} \mathrm{Hg}$ from oil-coated collector plates are also described. The preparation of thin osmium targets of platinum, and samarium isotopes by ion deposition in the sector isotope separator has been achieved. Summary tabulations are given of elements chemically processed and new lots of isotopes released to inventory.

\section{STABLE ISOTOPE SEPARATIONS}

Isotopic separations of tin and ytterbium were continued throughout the quarter, and a chlorine separation that was initiated early in January also ran throughout the period. These separations were conducted in a total of twenty-four $180^{\circ}$ separators on a 24-hr, 5-day-week basis. The ytterbium separation, which was started in late March 1975, with the goal of obtaining $\sim 6 \mathrm{~g}$ of $\geq 20 \%{ }^{168} \mathrm{Yb}$, was terminated on March 31, 1976, after attaining an estimated quantity equivalent to the stated requirement. A new short separation of germanium isotopes is scheduled to begin in the $255^{\circ}$ units on April 1, in order to recover $\geq 10 \mathrm{~g}$ of $\geq 90 \% \mathrm{Ge}$. This material, whirh is of a higher assay quality than previously attained, is intended for Sales distribution in uses such as Mössbauer research. 


\section{DEVELOPMENT ACTIVITIES}

\section{$255^{\circ}$ Separator Studies}

Since the last report, studies of the $255^{\circ}$ separation system have been continued with a dual objective: first, to acquire a better understanding of the basic factors limiting separator performance, and, second, to determine $255^{\circ}$ separator parameters that would yield $\geq 90 \%{ }^{73}$ Ge at a reasonable ion output (20 to $\left.25 \mathrm{~mA} \mathrm{Ge}{ }^{+}\right)$. Both objectives were pursued simultaneously. In the interest of economy in the forthcoming separation, an early decision was made to limit investigations to the use of existing 12-in.-radius Ion-exit-slit geometry. Similarly, the choice of charge materlal was reduced to $\mathrm{GeCl}_{4}$, based simply on its availability by a speciffed utilization date. Germanium tetrachloride was known to present neutral-vapor problems that resulted in the dilution of germanium isotopes with normal germanium. Thus the present work incorporated calcium-pumping as a means of controlling this problem and included a receiver having masses of ${ }^{76} \mathrm{Ge}$ and ${ }^{72} \mathrm{Ge}$ which were electrically monitorable. This receiver design (1) permitted periodic monitoring of the $\mathrm{Ge}-\mathrm{Ge}$ valley current for subsequent use in determining the quality of beam focus attained and (2) provided a means for the estimation of the quantity of isotopic material being collected.

Comparison of the performance of the systems having ion exit slits with dimensions of $1 / 8 \times 3 \mathrm{in}$, and $3 / 16 \times 3$ in. showed essentially equal quality of beams, with total ion output to the receiver averaging 19 and $27 \mathrm{~mA}$, respectively. Both ion output and beam quality (peak-to-valley ratio) were shown to be pressure dependent, as indicated in Fig. 1 . The curves plotted are typical of responses obtained by optimizing system parameters and then throttling the pumping system in ateps to produce an increase in system pressure. System pressure was attributable to $\mathrm{GeCl}_{4}$ input $(\sim 1 \mathrm{~g} / \mathrm{hr})$, atmospheric inleakage $(\sim 0.05 \mathrm{~g} / \mathrm{hr})$, and calcium vaporized onto the tank walls $(21.5 \mathrm{~g} / \mathrm{hr})$. The results leave little doubt that the effective separation of germanium isotopes requires operation at low pressure to overcome three basic difficulties: (1) low ion output, 
(2) poor beam quality or focus, and (3) contamination by deposition of neutral vapors of germanium.

In trial runs that were designed to. test proposed germanium-component geometry, 14 unit start-ups were introduced; the ion output averaged $26.0 \mathrm{~mA}$ for $60 \mathrm{hr}$ and the peak-to-valley ratios averaged 90 to 1 . Recovered Ge assayed $92.2 \%$, indicating that the system and the equipment chosen are capable of providing the $\geq 90 \%$ Ge set as a goal in the forthcoming separations series.

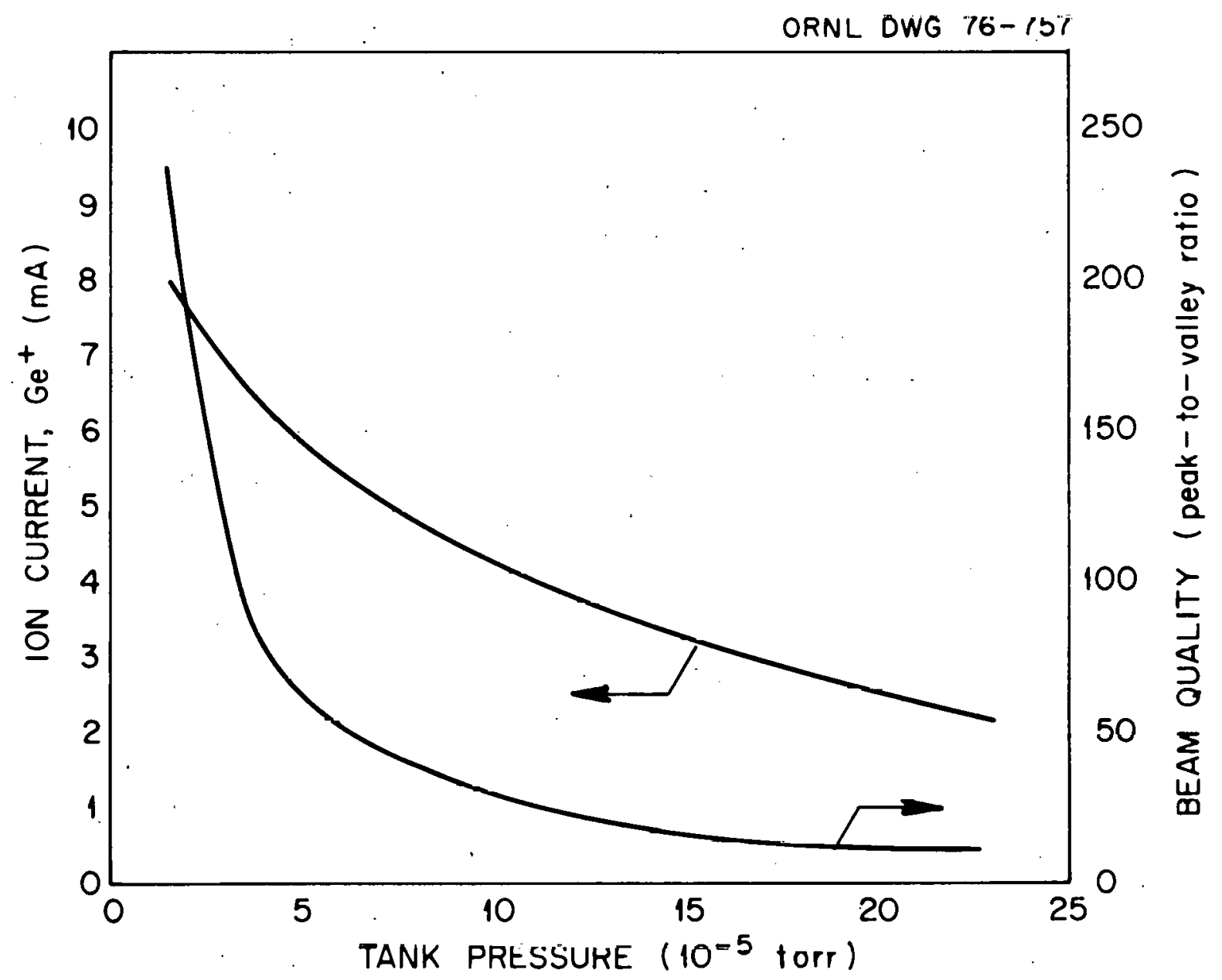

Fig. 1. Germanium 1on output and beam quality as a function of tank pressure. 


\section{Ytterbium Recycle Purification}

During the current ytterbium isotopic separation, which ran for $\sim 1$ year in order to obtain needed $\mathrm{Yb}$, it became economically necessary to recover and recycle the un-ionized portion of the charge material. At the outset, typical precipitation-type chemical separations were attempted to separate a large quantity of impurities (principally copper and iron) introduced by washing separator units. These procedures, however, became extremely time-consuming and inefficient due to the large volumes of solutions encountered.

As a means of reducing chemistry time and, at the same time, providing a purer charge material, an established solvent extraction procedure using pure tri-N-butyl phosphate (TBP) was tried. As a consequence, it was found that chemistry time could be reduced by about 15 hrs with very little $(\sim 0.002 \%)$ ytterbium 1ost, and would result in ytterbium oxide charge material of higher purity.

Bastcally, the principle is rather simple, although a large-volume evaporator and mixer-settler extraction equipment are necessary. Nitric acid wash solutions of calutron components (mainly sources and liners) are filtered on paper to remove solids, and the filtrates are evaporated to concentrate ytterbium. The solids (largely carbon) are ignited and the ash leached with hot $\operatorname{INN}_{3}(\sim 10 \mathrm{M})$. The insolubles are centrifuged for clarification, and the centrifugate is evaporated in a tantalum-lined evaporator using 30-psi steam pressure.

Approximately 8 liters of filtered evaporator concentrate is adjusted to $\sim 10 \underline{\mathrm{M}}$ in $\mathrm{HNO}_{3}$ and is then extracted batchwise with approximately 10 liters of pure TBP. Each batch of concentrate contains from 100 to $700 \mathrm{~g}$ of ytterbium. An additional 4 liters of TBP is run through the mixersettler extractor to ensure ytterbium removal. Ytterbium is atripped from the TBP with distilled water and recovered by precipitation with oxalic acid. After ignition, ytterbium oxide is pressed into buttons and recycled in the separator by means of in situ chlorination with carbon tetrachloride. 


\section{Mercury-202 Retention Study}

For some time now, the technique for collecting mercury isotopes in calutron units has been based on the decomposition of films of Octoil-s [di(2-ethylhexy1) sebacate] either in water-cooled copper pockets or on water-cooled copper plates. The collection principle appears to be dependent on the adsorption of mercury on the decomposed oil films. This procedure, which is a compromise between earlier trapping systems that employed water-cooled silver collector pockets and expensive liner refrigeration, produces relatively pure mercury isotopes without the need for a refrigeration system. Retention, that is, the ratio of monitored beam to the material actually recovered, is quite variable in mercury collections due to the high vapor pressure of the impinging metal ions. Retention of mercury (on oil films, in particular) appears to be dependent on the vapor pressure of mercury, ion output, size of collection plate, quality of the film itself, and the saturation of the deposit.

After the recovery and refinement of the products from a recent separation, a correlation of the ${ }^{202} \mathrm{Hg}$ retention values was made. The basis for the correlation was in terms of ion output and quantity monitored onto a copper plate, with an effective collection area of approximately $18 \mathrm{in.}^{2}$. In the separation series that was terminated on December 31,1975 , 15 runs were made in which the estimated weight of $\mathrm{Hg}$ was $<300 \mathrm{mg}$ and 27 runs in which the estimated weight was $>300 \mathrm{mg}$. The runs that had an estimated weight of $<300 \mathrm{mg}$ of ${ }^{202} \mathrm{Hg}$ had an average product retention of $40.5 \%$, while those with an estimated weight of $>300 \mathrm{mg}$ of $\mathrm{Hg}$ had an average retention of $28.1 \%$.

The correlation of retention values, based on 10 runs of highest retention and 10 runs of lowest retention, along with parameters such as beam collection time (innage hours) and collection rate, is shown in Table 1. 
Table 1. Correlation of ${ }^{202} \mathrm{Hg}$ retention values

$\begin{array}{cccccc}\text { Innage } & \text { Rate } & \text { Estimated } & \text { Recovery } & \text { Retention } & \text { Assay } \\ (\mathrm{hr}) & \text { (mg/ } & \text { weight } & \text { weight } & (\%) & (\%) \\ & \text { hr) } & (\mathrm{g}) & (\mathrm{g}) & & \end{array}$

\begin{tabular}{llllllll}
\hline $\begin{array}{l}\text { Average for } \\
10 \text { runs with } \\
\text { highest retention. }\end{array}$ & 70.0 & 4.22 & 0.295 & 0.144 & 48.8 & 95.6 \\
$\begin{array}{l}\text { Average for } \\
\begin{array}{l}10 \text { runs with } \\
\text { lowest retention }\end{array}\end{array}$ & 92.7 & 4.26 & 0.395 & 0.073 & 18.5 & 96.4 \\
\hline
\end{tabular}

These values indicate that, after $\sim 300 \mathrm{mg}$ of isotopic mercury has been depustited on this particular surface area, the surface becomes saturated, and additional mercury ions are lost from the collector. It seems evident, therefore, that it would be economically advantageous in future separations which utilize the same collection system to use a combination of parameters (natural abundance, ion output, and reception time) that would lead to only $300 \mathrm{mg}$ of deposit.

\section{TARGET PREPARATION BY ION DEPOSITION}

150 Isotopically enriched thin targets of ${ }^{186} \mathrm{Os},{ }^{192} \mathrm{Pt},{ }^{104} \mathrm{Pt}$, and Sm were prepared during the quarter in the $180^{\circ}$-sector isotope separator (ORSIS) by the surface deposition method. Two targets of. each isotope were prepared with deposition thicknesses of $25 \mu \mathrm{g} / \mathrm{cm}^{2}$ for ${ }^{194} \mathrm{Pt}$ and $\mathrm{Sm}$ and $50 \mu \mathrm{g} / \mathrm{cm}^{2}$ for ${ }^{186}$ os and ${ }^{192} \mathrm{Pt}$. The substrate, in every case, consisted of $75 \mu \mathrm{g} / \mathrm{cm}^{2}$ carbon foil. The ion beam was decelerated from about $35 \mathrm{kV}$ to $200 \mathrm{eV}$ at the point of impact on the substrate. The isotopic purfty of the wanted icotope was estimated to be $>99 \%$ in each case, and the initial feed was normal isotopic material. All of the targets were prepared for use in coulomb excitation studies. 
CHEMICAL PROCESSING

Material in Process

The following elements were in chemical processing during the quarter: chlorine, mercury, thallium, tin, and ytterbium.

\section{Material Added to Inventory}

Table 2 identifies the 1sotopic material that was released or made avallable to Sales during this report period; the appropriate separation data are also included. In addition to the eight new lots of isotopes released to Sales, 19 loan-return samples were processed and returned to Research Materials Collection (RMC) for inventory. 
Table 2. Operations status for the period Janiary-March 1976

\begin{tabular}{|c|c|c|c|c|c|c|c|c|c|c|}
\hline \multirow[b]{2}{*}{ Isotope } & \multirow[b]{2}{*}{ Series } & \multirow{2}{*}{$\frac{\text { Beries }}{\text { Start }}$} & \multirow{2}{*}{$\frac{\text { Schedule }}{\text { Finish }}$} & \multicolumn{2}{|c|}{ Hours } & \multirow{2}{*}{$\begin{array}{c}\text { Charge } \\
\text { material }\end{array}$} & \multirow{2}{*}{$\frac{\text { Recovery (g) }}{\text { Actual }}$} & \multirow{2}{*}{$\frac{\text { Purity }(\%)}{\text { Actual }}$} & \multicolumn{2}{|c|}{ Requirements } \\
\hline & & & & Innage & Tank & & & & Grams & Purity $(\%)$ \\
\hline 56 & & & & & & & & & & \\
\hline $\mathrm{Fe}$ & $\mathrm{OQ}$ & $6: 23 / 69$ & $2 / 26 / 71$ & 61,231 & 85,128 & $\mathrm{FeCl}_{2}$ & 8916.66 & 99.87 & 6000 & $>99.8$ \\
\hline${ }^{196} \mathrm{Hg}$ & QB & $8,11 / 75$ & $12 / 31 / 75$ & 3,517 & 4,704 & $\mathrm{Hg}$ & 0.255 & 20.99 & 50 & $>48$ \\
\hline${ }^{202} \mathrm{Hg}$ & $\mathrm{QB}$ & $8 ; 11 / 75$ & $12 / 31 / 75$ & 3,519 & 4,704 & $\mathrm{Hg}$ & 4.487 & 96.32 & 50 & $\geq 95$ \\
\hline${ }^{123} \mathrm{Te}$ & PS & $3 / 15 / 74$ & $3 / 21 / 75$ & 22,817 & 27,340 & $\mathrm{Te}$ & 1.092 & 46.85 & 13 & $>80$ \\
\hline${ }^{124} \mathrm{Te}$ & PS & $3 i 15 / 74$ & $3 / 21 / 75$ & $22,81 ?$ & 27,340 & $\mathrm{Te}$ & 26.932 & 95.42 & & \\
\hline${ }^{124} \mathrm{Te}$ & PS & $3 ! 15 / 74$ & $3 / 21 / 75$ & $22,81 ?$ & 27,340 & $\mathrm{Te}$ & 26.545 & 93.75 & 100 & $>95$ \\
\hline${ }^{125} \mathrm{Te}$ & PS & $3: 15 / 74$ & $3 / 21 / 75$ & 22,817 & 27,340 & $\mathrm{Te}$ & 29.814 & 95.67 & 100 & $90-97$ \\
\hline $203 \mathrm{Tl}$ & QA & $8,6 / 75$ & $12 / 31 / 75$ & $1 \bar{i}, 960$ & 14,304 & $\mathrm{~T} 1$ & 524.022 & 92.36 & 600 & $>90$ \\
\hline
\end{tabular}


INTERNAL DISTRIBUTION

ORNL/TM- 5465

1. G. M. Banic

2. W. A. Bell, Jr.

3. K. B. Brown

4. J. W. Cleland

5. T. F. Connolly

6. F. L. Culler, Jr.

7. W. C. Davis

8. D. E. Ferguson

9. H. R. Gwinn

10. J. A. Harvey

11. J. E. Keeton

12. 0. L. Keller

13. E. Lamb

14. F. C. Maiensche in

15-19. E. Newman

20. F. G. Perey

21. H. Postma

22. W. K. Prater

23. J. E. Ratledge

24. F. M. Scheitlin

25-26. K. A. Spainhour
27. P. H. Stelson

28. J. G. Tracy

29. D. B. Trauger

30. J. R. Weir

31. J. C. White

32. M. K. Wilkinson

33. R. G. Wymer

34. J. O. Younghanse

35. A. Zucker

36. W. K. Davis (consultant)

37. J. C. Frye (consultant)

38. C. H. Ice (consultant)

39. I. T. Katz (rnnsult tant)

40. L. O. Love (consultant)

41. R. B. Richards (consultant)

42. Laboratory Records - RC

43-52. Laboratory Records Department

53. ORNL Patent Section

54-55. Central Research Library

56. Document Reference Section

\section{EXTERNAL DISTRIBUTION}

57. N. F. Barr, Office of General Manager, ERDA, Washington, DC 20545

58. R. C. Block, Rensselaer Polytechnic Institute, Troy, NY 12181

59. R. M. Brugger, Aerojet Nuclear Company, Idaho Falls, ID 83401

60. J. L. Burnett, Division of Physical Research, ERDA, Washington, DC 20545

61. R. E. Chrien, Brookhaven National Laboratory, Upton, NY 11973

62. J. T. Christy, ERDA-RL00, Richland, Washington 99352

63. G. A. Cowan, Los Alamos Scientific Laboratory, Los Alamos, NM 87545

64. B. J. Dropesky, T.ns Alamos Scientific Laboratory, Los Alamos, NM 87545

65. L. Friedman, Brookhaven National Laboratory, Upton, NY 11973

66. K. A. Gschneidner, Jr., Iowa State University, Metallurgy and Ceramics, Ames, IA 50011

67. M. E. Harris, Lawrence Livermore Laboratory, Livermore, CA 94550

68. R. W. Hoff, Lawrence Livermore Laboratory, Livermore, CA 94550

69. H. E. Jackson, Argonne National Laboratory, Argonne, IL 60439

70. J. A. Lenhard, Research and Technical Support Division, ERDA-ORO

71. R. H. Leonard, Florida State University, Nuclear Research Bldg. No. 51, Tallahassee, FL 32306

72. J. L. Lerner, Argonne National Laboratory, Chemistry Division, Argonne, IL 60439 
73. J. N. Maddox, Division of Biomedical and Environmental Research, ERDA, Washington, DC 20545

74. W. B. Mann, National Bureau of Standards, Washington, DC 20234

75. J. W. Meadows, Lawrence Livermore Laboratory, Livermore, CA 94550

76. M. C. Michel, Lawrence Berkeley Laboratory, Berkeley, CA 94720

77. R. A. Naumann, Princeton University, Chemical Sciences, Princeton, NJ 08540

78. H. W. Newson, Duke University, Physics Department, Durham, NC 27706

79. H. A. O'Brien, Los Alamos Scientific Laboratory, Los Alamos, NM 87545

80. G. L. Rogosa, Division of Physical Research, ERDA, Washington, DC 20545

81. B. C. Rusche, Savannah River Laboratory, Aiken, SC 29810

82. L. G. Stang, Brookhaven National Laboratory, Upton, NY 11973

83. W. L. Talbert, Jr., Iowa State University, Nuclear Science, Ames, IA 50011

84. G. Taplin, University of California, Los Angeles, CA 90024

85-89. D. H. Turno, Savannah River Laboratory, Aiken, SC 29810

90. M. Williams, Lawrence Livermore Laboratory, Livermore, CA 94550

91-117. Technical Information Center, ERDA-OR 